\title{
MOTYWACJA I NASTAWIENIA POLSKICH UCZNIÓW DO NAUKI JĘZYKA NIEMIECKIEGO W KONTEKŚCIE RÓŻNIC REGIONALNYCH I POSTRZEGANIA SPOŁECZEŃSTWA NIEMIECKIEGO
}

\author{
Motivation and attitude of Polish learners towards learning German \\ considered with reference to regional differences and perceptions \\ of German society
}

The purpose of the article is to present the motivation and attitude of Polish students towards learning German. The analysis presented is based on research conducted by the author in junior and senior high schools throughout Poland. The findings indicate that the predominant motive for learning German is instrumental. Motivation connected with communication is of less importance in the east of Poland than in the western part of the country. Motivation concerning the culture of German speaking countries does not seem to be relevant for Polish students. There is a strong correlation between increasing and decreasing motivation to learn German and the image of a German person and the attitude towards the German nation: those students who are positively motivated to learn the language present an extremely positive attitude towards German society, while those with lower motivation exhibit strong prejudice against Germans.

\section{Wprowadzenie}

Dość powszechne jest przekonanie o słabnącym znaczeniu języka niemieckiego jako przedmiotu w polskich szkołach. Dzieje się tak, pomimo wyraźnie rosnącej liczby gimnazjalistów uczących się języka niemieckiego (por. 
ORE, 2011), co wiąże się z wprowadzeniem w 2009 roku obowiązkowego drugiego języka do gimnazjów. Także globalne statystyki, dotyczące powszechności uczenia się języka niemieckiego jako obcego, wskazują na pierwsze miejsce Polski w tym rankingu (Netzwerk Deutsch, 2010).

Jednocześnie żywy jest mit o niemieckim jako języku nielubianym przez wielu uczniów. Poza tym język ten, podobnie jak inne wiodące języki nowożytne, znajduje się, co jest bezsporne, pod wielką presją języka angielskiego jako ogólnoświatowej „lingua franca”. Zapytani o ocenę motywacji swoich uczniów do nauki j. niemieckiego, i poproszeni o wystawienie szkolnej noty tejże motywacji, nauczyciele germaniści ze szkół podstawowych, gimnazjów oraz szkół ponadgimnazjalnych w całej Polsce oceniają ją na „dobry" (średnia ocen: 3,9 w skali 1-6) ${ }^{1}$. Poszczególne relacje nauczycieli pokazują przy tym, jak rozmaita jest sytuacja j. niemieckiego w różnych szkołach i jak zróżnicowana motywacja uczniów. Zapytani o istnienie negatywnych stereotypów Niemiec i Niemców panujących wśród uczniów, obniżających znacząco motywację do nauki j. niemieckiego, nauczyciele także malują niejednoznaczny obraz. Co czwarty nauczyciel przyznaje, że wśród uczniów pokutują negatywne stereotypy Niemców, które wpływają negatywnie na motywację uczniów. We wschodniej i zachodniej Polsce odsetek krytycznie oceniających tę sytuację jest podobny, jednocześnie więcej nauczycieli z woj. zachodnich zaprzecza istnieniu uprzedzeń wpływających na motywację.

Obserwacje nauczycieli to tylko jedna strona medalu, drugą, niezwykle istotną i wartą zbadania, jest opinia samych uczniów na temat ich motywacji do nauki j. niemieckiego i ich stosunku do społeczeństwa języka docelowego. Motywacja w uczeniu się języków obcych składa się z wielu komponentów, które wynikają z osobowości i biografii ucznia, ale także m.in. z jego nastawień i orientacji wobec języka obcego i związanej z nim kultury (Riemer, 2006: 36). Jednocześnie obiektem badań może być z jednej strony motywacja sensu largo, rozumiana jako generalna i stosunkowo trwała postawa czy gotowość do pewnego działania (tu: uczenia się języka), z drugiej zaś strony motywacja sensu stricto, a więc aktualna motywacja w określonej sytuacji (w procesie uczenia się przede wszystkim stan bieżący podczas zajęć) (por. Apelt, 1992: 86). Choć sformułowanie Apelta o "stałym sposobie zachowania się" (ibidem) w odniesieniu do motywacji sensu largo może razić nieuwzględnieniem dynamicznego charakteru motywacji podkreślanego w ostatnich latach (por. np. Dörnyei, 2001; Pawlak, 2012), to chcemy w poniższych rozważaniach skupić się

\footnotetext{
${ }^{1}$ Wyniki niepublikowanych badań Autora przeprowadzonych dla Instytutu Goethego w Warszawie w roku szk. 2010/2011 na próbie 292 nauczycieli j. niemieckiego reprezentujących wszystkie typy szkół we wszystkich 16 województwach Polski.
} 
właśnie na motywacji w szerszym sensie. Niniejszy artykuł ma na celu przybliżenie, w oparciu o badania empiryczne, problemu motywacji polskich uczniów do nauki języka niemieckiego, także z uwzględnieniem różnic regionalnych i nastawienia do społeczeństwa niemieckiego.

\section{Pytania badawcze}

Badanie ankietowe wśród uczniów polskich gimnazjów i szkół ponadgimnazjalnych odbyło się w ramach zewnętrznej ewaluacji projektu DeutschWagen-Tour (DWT), w ciągu jego pierwszej edycji. Projekt ten, realizowany od kwietnia 2009 r. przez Instytut Goethego w Warszawie we współpracy z Niemiecką Centralą Wymiany Zagranicznej (DAAD), ma na celu popularyzację języka niemieckiego i kultury niemieckiej wśród polskich uczniów i studentów ${ }^{2}$. Zasadniczą formą realizacji tych zamierzeń są wizyty moderatorów DWT, którzy bezpośrednio w szkołach przeprowadzają animacje językowe zarówno z uczącymi się j. niemieckiego, jak i z uczniami, którzy nie uczestniczą w zajęciach tego języka. Badanie ankietowe obejmowało wyłącznie tych uczniów, którzy w takich animacjach brali udział i dotyczyło zarówno ogólniejszych doświadczeń z nauką języka obcego, jak i refleksji związanej z wizytą DWT. Ankieta przeznaczona dla gimnazjalistów i uczniów szkół ponadgimnazjalnych przygotowana została w dwóch wariantach: dla uczących się i dla nieuczących się j. niemieckiego. Standardowe badanie uczących się j. niemieckiego obejmowało następujący zakres:

- Nauka języków obcych;

- Nauka języka niemieckiego;

- Motywacja do uczenia się j. niemieckiego;

- Nastawienie do języka niemieckiego i Niemiec;

- Ewaluacja wizyty DWT.

Dla potrzeb niniejszego artykułu zostaną wykorzystane części ankiety badające motywy i nastawienia uczniów oraz ich obraz społeczeństwa i kultury niemieckiej. Przed podjęciem badań ankietowych sformułowano dla tego obszaru następujące pytania badawcze:

\footnotetext{
${ }^{2} \mathrm{~W}$ bardziej szczegółowym ujęciu są to następujące cele: promocja języka niemieckiego jako obcego w Polsce; zwiększenie motywacji uczniów już uczących się języka niemieckiego; prezentowanie pozytywnego wizerunku Niemiec i ich mieszkańców; przybliżenie dziedzictwa kulturowego Niemiec; promowanie idei sieci szkół partnerskich PASCH (Schulen: Partner der Zukunft); prezentacja Niemiec jako miejsca przyszłych studiów akademickich.
} 
1. Jakie motywy towarzyszą polskim uczniom w nauce języka niemieckiego?

2. Czy istnieją różnice regionalne w motywacji?

3. Jak dynamiczna, w ocenie uczniów, jest ich motywacja?

4. Jakie jest nastawienie uczniów do j. niemieckiego i jego nauki?

5. Jak oceniana jest przez uczniów przydatność tego języka?

6. Jak postrzegani są Niemcy i jak skorelowany jest ten wizerunek z motywacją do uczenia się j. niemieckiego?

Historyczne, geopolityczne i czysto geograficzne czynniki, a także statystyki dotyczące powszechności nauczania j. niemieckiego w polskich szkołach (por. ORE, 2011) oraz dotychczasowe badania Autora nad regionalnym zróżnicowaniem obrazu Niemiec wśród polskich uczniów (Mackiewicz, 2012), dają podstawy do sformułowania hipotezy, iż także charakter motywów do uczenia się j. niemieckiego uzależniony jest w pewnym stopniu od regionu, w którym uczeń jest socjalizowany i w którym uczestniczy w zajęciach tego języka. Stąd też część wyników zaprezentowana zostanie także z uwzględnieniem podziału na Polskę wschodnią i zachodnią odpowiadając na pytanie badawcze $\mathrm{nr} 2$.

Ponieważ ewaluacja projektu obejmowała także ankietowanie nauczycieli j. niemieckiego, poniższa analiza zostanie uzupełniona o odpowiedź na dodatkowe pytanie badawcze: Czy w opinii nauczycieli istnieją wśród uczniów negatywne stereotypy Niemiec i Niemców obniżające znacząco motywację do nauki j. niemieckiego?

\section{Metodologia i przebieg badania}

Ankieta skierowana do uczniów zawierała pytania zamknięte (jednokrotnego i wielokrotnego wyboru), półotwarte i otwarte. Tym samym badanie uwzględniało zarówno elementy metody ilościowej, jak i jakościowej. Oprócz „metryczki” zawierającej dane na temat płci, wieku, typu szkoły, klasy czy województwa, uczniowie odnosili się (w części poświęconej motywacji, nastawieniom i obrazowi Niemiec i Niemców) do następujących pytań:

a) Jakich języków obcych uczysz się obecnie? (wielokrotny wybór)

b) Czy niemiecki jest twoim pierwszym językiem obcym? (jednokrotny wybór)

c) Ile lat uczysz się już j. niemieckiego? (jednokrotny wybór)

d) Czy uczysz lub uczyłeś się niemieckiego także poza szkołą? (jednokrotny wybór)

e) Czy byłeś już w kraju niemieckojęzycznym? (jednokrotny wybór)

f) Dlaczego zacząłeś/ zaczęłaś się uczyć języka niemieckiego? (wielokrotny wybór) 
Motywacja i nastawienia polskich uczniów do nauki języka niemieckiego...

g) Co obecnie motywuje Ciebie do nauki języka niemieckiego? (wielokrotny wybór)

h) Czy zauważasz, że teraz masz mniejszą chęć do uczenia się języka niemieckiego niż na początku nauki? (jednokrotny wybór)

i) Czy uważasz, że nauka języka niemieckiego jest trudna? (jednokrotny wybór)

j) Język niemiecki jest... (pytanie półotwarte)

k) Czy myślisz, że j. niemiecki przyda Ci się w przyszłości? (jednokrotny wybór)

I) Jakie masz skojarzenia z Niemcami jako krajem? (pytanie otwarte)

m) Niemcy (ludzie) są... (pytanie półotwarte)

n) Jakich Niemców kojarzysz? (pytanie otwarte)

Z metodologicznego punktu widzenia wskazana była szczególna ostrożność przy formułowaniu pytań i wybieraniu ich formy. Należało uwzględnić fakt, że respondentami będzie młodzież, która raczej rzadko uczestniczy w takich badaniach i do tego częściej niż osoby starsze może wykazywać skłonności do bezrefleksyjnego podejścia do ankiety. Z tego powodu przy pytaniach o skojarzenia zrezygnowano np. $z$ dyferencjału semantycznego, a przy pytaniach o motywy nie skorzystano ze skali Likerta, bardziej precyzyjnej i odpowiedniej dla zaawansowanych ilościowych metod statystycznych. Testy próbne, przeprowadzone na mniejszych grupach poznańskich uczniów dla zapewnienia jak najwyższego stopnia rzetelności i trafności, potwierdziły po części przypuszczenie, że stosunkowo niski wiek badanych wiąże się z potencjalnym ryzykiem zbyt szybkiego i nieprzemyślanego zakreślenia wybranej cechy czy stanowiska. Dlatego w części badania dotyczącej skojarzeń zaproponowano pytania otwarte, które wymagają więcej zaangażowania i niejako zmuszają ucznia do bardziej intensywnych przemyśleń, a przy tym wzbogacają badanie o cechy jakościowe. W pytaniu o motywy wykorzystano natomiast zadanie wielokrotnego wyboru o kafeterii półotwartej. Przy wykorzystaniu tego instrumentu także istnieje, co prawda, ryzyko nieprzemyślanego zaznaczenia danej opcji, jednak testy próbne (metodą powtórnego pomiaru) potwierdziły większą rzetelność tego instrumentu niż skali Likerta. Instrument ten jest dla młodszych respondentów bardziej przejrzysty i jednoznaczny, wykorzystanie go wymagało też mniej czasu. Należy pamiętać, że omawiane testy ewaluacyjne realizowane były przy okazji wizyty DWT, a nie były ankietami stricte badającymi motywację, korzystającymi ze szczególnego wsparcia logistycznego i organizacyjnego w ramach osobnego projektu, jak np. podczas badań motywacji wśród polskich uczniów j. angielskiego w Warszawie i Puławach (Gardner, 2010; Gardner, 2012).

Poniższa analiza opiera się na wynikach uzyskanych w roku szkolnym 2010/2011 oraz w pierwszych czterech miesiącach roku szkolnego 2012/2013 (wrzesień-styczeń) na próbie 675 uczniów gimnazjów i szkół ponadgimnazjal- 
nych uczących się j. niemieckiego jako przedmiotu obowiązkowego. Badana grupa obejmowała 474 gimnazjalistów (70,2\%) oraz 201 (29,8\%) licealistów ew. uczniów techników. 57,2\% stanowiły dziewczęta, a 42,8\% - chłopcy. Większość badanych mieściła się w przedziale wiekowym 14-17 lat: 14 lat - 29,6\%, 15 lat - 25,8\%, 16 lat - 10,8\%, 17 lat - 14,5\%. Pozostali uczniowie byli albo trochę młodsi (12,8\%), albo nieco starsi (6,5\%).

Ankieta objęła uczniów z całego kraju, który na potrzeby logistyczne projektu DWT podzielony został na pięć regionów. Każdy region jest reprezentowany w badaniu przez zbliżoną liczbę respondentów: Kielce (Polska Centralna i Południowa ${ }^{3}$ ) - 18,7\%, Lublin (Polska Wschodnia) - 21,6\%, Olsztyn (Polska Północna i Północno-Wschodnia) - 18,8\%, Poznań (Polska Zachodnia i Północno-Zachodnia) - 20,3\%, Wrocław (Polska Południowo-Zachodnia) - 20,6\%.

Ankieta miała formę elektroniczną i została każdorazowo przeprowadzona w salach komputerowych szkół pod nadzorem nauczycieli współpracujących z projektem.

\section{Wyniki badań}

Odpowiedzi na pytania, jakich języków obcych respondenci aktualnie się uczą i czy j. niemiecki jest pierwszym językiem obcym, są potwierdzeniem istniejącej hierarchii wśród języków obcych jako przedmiotów w polskich szkołach, wykazywanej np. w raportach na temat powszechności nauczania języków obcych (por. ORE, 2011). W związku ze specyfiką grupy badawczej, którą tworzyli wyłącznie uczący się j. niemieckiego, wszyscy (675) zadeklarowali uczenie się tego właśnie języka, jednocześnie jednak aż 629 osób podało także j. angielski. Inne języki (francuski, hiszpański, rosyjski) odegrały w tej statystyce marginalną rolę.

Dominująca pozycja j. angielskiego została także potwierdzona poprzez drugie pytanie: aż 78\% respondentów podało język angielski jako pierwszy język obcy, tylko dla 22\% pierwszym językiem obcym jest niemiecki. Naturalną konsekwencją takiego stanu rzeczy jest duży odsetek badanych uczących się j. niemieckiego dopiero od roku lub krócej (34,7\%). Dwa lata nauki j. niemieckiego podało 17\%, trzy lata - 8,3\%, cztery lata - 9\%. Od czterech do ośmiu lat uczy się $24,5 \%$ badanych, natomiast więcej niż osiem lat nauki j. niemieckiego zadeklarowało 6,5\%. Język niemiecki jest przy tym przede wszystkim przedmiotem szkolnym, tylko $20 \%$ badanych uczyło się lub uczy tego języka także poza szkołą.

\footnotetext{
${ }^{3}$ W drugim cyklu projektu (od lutego 2012 r.) centrum obsługi tego regionu zostało przeniesione do Krakowa.
} 
Motywacja i nastawienia polskich uczniów do nauki języka niemieckiego...

Pytanie o powody rozpoczęcia nauki języka niemieckiego sformułowane jako pytanie wielokrotnego wyboru o charakterze półotwartym także pokazuje silne powiązanie tego języka z programem szkolnym i, w związku z tym, z pewnym „przymusem” jego nauki. Kafeteria tego pytania uwzględniała kilka zasadniczych powodów, dając jednocześnie możliwość dodania innego powodu. Częstotliwość odpowiedzi kształtuje się następująco:

- Musiałem wybrać ten język w szkole - 58,1\%

- Chciałbym móc się porozumieć z np. z Niemcami - 27\%

- Podoba mi się ten język - $24 \%$

- Tak zdecydowali rodzice - 12,9\%

- Inny powód - 9,6\%

- Interesują mnie kraje niemieckojęzyczne oraz ich kultura - 8,1\%

- Wybrałem w szkole niemiecki, żeby uniknąć zajęć z języka, którego nie lubię - 7\%

- Zrobiłem/zrobiłam to pod wpływem kolegów/ koleżanek - 2,8\%.

Wśród innych powodów pojawiał się przede wszystkim „obowiązkowy przedmiot”, co mogło zostać wyrażone przez zaznaczenie pierwszej podanej opcji, ale dopisywano także powody oznaczające $w$ istocie nastawienie do języka („fajny język”) lub, sporadycznie, związane z sytuacją rodzinną lub indywidualnymi planami („rodzina w Niemczech”, „praktyki w Niemczech”, „planowany wyjazd do Austrii”).

Kluczowym dla niniejszego badania było pytanie o aktualne motywy („Co obecnie motywuje Ciebie do nauki języka niemieckiego?”). Zbiorcze wyniki zawarto w tabeli 1 . Tabela uwzględnia także osobne wyniki dla Polski Wschodniej i Zachodniej ${ }^{4}$.

\begin{tabular}{|l|l|l|l|}
\hline Motyw & $\begin{array}{l}\text { Wszyscy } \\
\text { badani } \\
(\mathbf{n = 6 7 5 )}\end{array}$ & $\begin{array}{l}\text { Polska } \\
\text { Wschodnia } \\
(\mathbf{n = 2 0 5})\end{array}$ & $\begin{array}{l}\text { Polska Za- } \\
\text { chodnia } \\
(\mathbf{n = 2 2 9})\end{array}$ \\
\hline $\begin{array}{l}\text { konieczność zaliczenia tego języka w szkole, uzyskanie } \\
\text { pozytywnej oceny }\end{array}$ & $1486,4 \%)$ & $144(70,2 \%)$ & $148(64,2 \%)$ \\
\hline uznanie i zachęta ze strony rodziców i rodziny & $95(14,1)$ & $24(11,7 \%)$ & $27(11,8 \%)$ \\
\hline może wyjadę wkrótce za granicę i niemiecki przyda mi się & $291(43,1 \%)$ & $81(39,5 \%)$ & $106(46,3 \%)$ \\
\hline $\begin{array}{l}\text { mam znajomego/znajomych za granicą i chcę się z nimi } \\
\text { coraz lepiej porozumiewać }\end{array}$ & $88(13.0 \%)$ & $12(5,9 \%)$ & $39(17,0 \%)$ \\
\hline $\begin{array}{l}\text { chcę czytać niemieckie książki, oglądać filmy po niemiec- } \\
\text { ku, rozumieć piosenki }\end{array}$ & $75(11,1 \%)$ & $21(10,2 \%)$ & $33(14,4 \%)$ \\
\hline
\end{tabular}

\footnotetext{
${ }^{4}$ Podział na potrzeby badań: Polska Wschodnia - Lubelskie, Podkarpackie, Podlaskie, Świętokrzyskie, Warmińsko-Mazurskie; Polska Zachodnia - Dolnośląskie, Lubuskie, Śląskie, Opolskie, Wielkopolskie, Zachodniopomorskie.
} 
Maciej Mackiewicz

\begin{tabular}{|l|l|l|l|}
\hline $\begin{array}{l}\text { chcę korzystać z niemieckojęzycznych stron interneto- } \\
\text { wych }\end{array}$ & $60(8,9 \%)$ & $12(5,9 \%)$ & $26(11,4 \%)$ \\
\hline $\begin{array}{l}\text { chcę poprzez ten język lepiej poznać Niemców, Austria- } \\
\text { ków, Szwajcarów }\end{array}$ & $93(13,8 \%)$ & $24(11,7 \%)$ & $37(16,2 \%)$ \\
\hline uważam, że w Europie powinno się znać niemiecki & $167(24,7 \%)$ & $41(20 \%)$ & $65(28,4 \%)$ \\
\hline nauka niemieckiego to dla mnie przyjemność, zabawa & $139(20,6 \%)$ & $46(22,4 \%)$ & $59(25,8 \%)$ \\
\hline inne motywy & $38(5,6 \%)$ & $9(4,4 \%)$ & $11(4,8 \%)$ \\
\hline
\end{tabular}

Tabela 1: Aktualne motywy uczniów do uczenia się j. niemieckiego.

Charakterystyczna jest ogromna przewaga odpowiedzi: „Konieczność zaliczenia tego języka w szkole, uzyskanie pozytywnej oceny”. Może ona wskazywać na silną motywację zewnętrzną o charakterze instrumentalnym, gdzie osiągnięcie dobrej oceny albo zaliczenie przedmiotu jest celem nadrzędnym. Należy podkreślić, iż w ramach grupy respondentów, którzy tę opcję wybrali, prawie połowa (46\%) nie zaznaczyła żadnej innej odpowiedzi. W tych przypadkach można założyć skrajnie instrumentalną motywację. Opcja „Może wyjadę wkrótce za granicę i niemiecki przyda mi się”, którą można interpretować jako „motyw „komunikacyjny” (Apelt, 1992), jawi się w ramach całej próby badawczej jako drugi najważniejszy motyw. Jednak dla wyraźnie większej części badanych ten pragmatyczny motyw nie odgrywa żadnej roli, lub nie jest on jeszcze w pełni uświadamiany. Inny pragmatyczny motyw, związany z wykorzystywaniem niemieckojęzycznych źródeł, w tym tak bliskich i dostępnych uczniom jak strony internetowe, jest także nadzwyczaj słabo reprezentowany.

W tabeli 1 uwzględnione zostały także szczegółowe wyniki dla wschodnich i zachodnich województw. Wynika z nich procentowy udział wskazań na dany motyw w ramach jednej lub drugiej części kraju. Hipoteza dotycząca różnic regionalnych w motywacji uczniów została w znacznym stopniu potwierdzona. Motyw instrumentalny jest we wschodniej Polsce bardziej rozpowszechniony niż w województwach zachodnich. Jeszcze większa jest różnica w przypadku motywu związanego z porozumiewaniem się ze znajomymi za granicą. Uczniowie z województw zachodnich wymieniają ten motyw o wiele częściej niż ich koledzy i koleżanki ze wschodniej Polski. Widać tutaj wyraźną korelację pozytywną ze zmienną dotyczącą bezpośrednich, „prymarnych” doświadczeń z krajami niemieckojęzycznymi. Na pytanie: „Czy byłeś już w kraju niemieckojęzycznym?", w skali całego kraju 60,6\% uczniów odpowiedziało przecząco, 35,4\% uczniów było w Niemczech, 14,1\% w Austrii i 4,3\% w Szwajcarii. 45\% uczniów z zachodniej Polski nie wyjeżdżało do tych krajów, tymczasem w województwach wschodnich aż 74\% badanych nie zna żadnego kraju niemieckojęzycznego z autopsji. Tym samym, dla mniejszego odsetka uczniów 
z regionów wschodnich j. niemiecki kojarzy się z autentyczną komunikacją, a motyw komunikacyjny jest odpowiednio rzadziej wymieniany.

Dynamiczność motywacji uczniów i jej procesowy charakter nie mogły zostać zbadane w perspektywie długoterminowej, zadano więc pytanie o subiektywne odczucia odnośnie zmieniającej się w czasie motywacji. Na prosto sformułowane pytanie: „Czy zauważasz, że teraz masz mniejszą chęć do uczenia się języka niemieckiego niż na początku nauki?" twierdząco odpowiedziało $16 \%$ uczniów, przecząco (co implikowało stały poziom motywacji) zareagowało $35 \%$. Większą chęć do nauki j. niemieckiego zadeklarowało $18 \%$. Od jednoznacznej odpowiedzi („trudno powiedzieć”) wstrzymało się jednak aż 31\% badanych, co może świadczyć o brakującej refleksji nad tym zjawiskiem. Ponieważ badani stwierdzający coraz mniejszą chęć do nauki j. niemieckiego mieli możliwość podania przyczyn tej negatywnej tendencji (pytanie otwarte), można stwierdzić, że czynnikami stopniowo demotywującymi były w większości przypadków „trudność” tego języka oraz negatywny do niego stosunek.

Interesująco rozkładają się odpowiedzi na pytanie dotyczące ogólnego nastawienia do nauki j. niemieckiego. Odsetek tych, którzy uważają, że nauka tego języka jest trudna, jest w skali całej próby prawie taki sam, jak tych, którzy przeczą temu twierdzeniu. Zdecydowanie lub raczej skłaniający się do tezy, że j. niemiecki jest trudny do nauczenia się, stanowią $44 \%$ badanych. Całkowicie odwrotną opinię reprezentuje $42 \%$ uczniów, a $14 \%$ nie ma w tej kwestii zdania. Zauważalna jest jednak zależność pomiędzy kierunkiem zmiany motywacji a opinią o stopniu trudności j. niemieckiego. W grupie osób deklarujących stabilny lub nawet rosnący poziom motywacji (359), zarejestrowano znacznie większy odsetek odpowiedzi $(56,3 \%)$ sugerujących niższy stopień trudności tego języka. W tej samej grupie, 31,7\% badanych uważa j. niemiecki za trudny. W grupie osób o spadającej motywacji proporcje są odwrotne: prawie $71 \%$ uważa ten język za trudny, a tylko prawie $23 \%$ raczej lub (rzadziej) zdecydowanie nie zgadza się z tą tezą.

Chcąc uzyskać bardziej zróżnicowane informacje na temat nastawienia do j. niemieckiego, postawiono respondentom półotwarte pytanie, polegające na dokończeniu zdania: „Język niemiecki jest...”. Skojarzenia pozytywne lub neutralne zdecydowanie dominują, podało je 76\% uczniów. Wśród najczęstszych skojarzeń wymienia się „fajny”, „prosty”, „ciekawy”. Najczęstsza neutralna odpowiedź to "język obcy". Negatywne skojarzenia ma $24 \%$ badanych, a najczęściej wymieniane to "trudny", poza tym także przede wszystkim "nudny" i „brzydki”.

Motywy pragmatyczne związane są z przekonaniem o przydatności j. niemieckiego w przyszłości. Przy tym pytaniu, z jednej strony zdecydowanie przeważa przekonanie o przydatności tego języka (45\%) nad nastawieniem negatywnym (13\%), z drugiej jednak strony zastanawiający jest fakt 
dużego odsetka osób niezdecydowanych (42\%). Hipotetycznie można było założyć, że w zachodnie Polsce świadomość przydatności tego języka będzie zdecydowanie większa. Tak jest $w$ istocie, jednak różnice między zachodnimi a wschodnimi województwami nie są radykalne: w zachodniej Polsce $49 \%$ uważa j. niemiecki za przydatny w przyszłości, we wschodniej natomiast sądzi tak $43 \%$. Co ciekawe, za nieprzydatny uważa niemiecki w obu częściach kraju ten sam odsetek (13\%).

Inspirując się teorią Gardnera i Lamberta (1972), która zakłada wprost proporcjonalną zależność pomiędzy motywacją a m.in. nastawieniem do społeczności języka docelowego, niniejsze badanie uwzględniło pozyskanie od respondentów danych, jak są przez nich postrzegane Niemcy i jej mieszkańcy w celu zarówno naszkicowania ogólnego obrazu Niemiec i Niemców w oczach uczących się j. niemieckiego dzieci i młodzieży, jak i dla zbadania korelacji pomiędzy poziomem motywacji a nastawieniem do Niemców. W tym miejscu zrezygnujemy z pełnej analizy wizerunku Niemiec panującego wśród młodych Polaków, która została już dokonana w innym artykule (Mackiewicz, 20125), skupimy się natomiast tylko na jednym, półotwartym zadaniu, które miało pokazać najsilniejsze skojarzenia z mieszkańcami Niemiec i spojrzymy na odpowiedzi w kontekście deklarowanej motywacji. Dokończenie zdania: „Niemcy są..." wykazało przede wszystkim, czy skojarzenia uczniów mają charakter kognitywny czy raczej afektywny, a więc czy wyrażają w pierwszym rzędzie nastawienia. Najczęściej wpisywane odpowiedzi to: mili - 19\%, przyjaźni/ uprzejmi $-11,5 \%$, fajni/ super $-6 \%$, sympatyczni $-5 \%$, brzydcy $-4 \%$, porządni/dokładni/ perfekcyjni - 3,5\%, dziwni - 3\%, punktualni - 2,5\%. Wynika z tego, że większość skojarzeń wyrażała przede wszystkim nastawienia uczniów do zachodnich sąsiadów. Ogółem $77 \%$ uczniów wymieniało przy tym tylko pozytywne atrybuty Niemców, lub (aczkolwiek rzadko) podawało neutralne skojarzenia (np. „inni”). 15\% wykazało negatywne skojarzenia, zaś $8 \%$ wstrzymało się od opinii („,nie wiem”, „trudno powiedzieć”, „nie znam” itp.).

O ile w ogólnej próbie pozytywne nastawienia uczniów zdecydowanie dominują, o tyle inaczej kształtują się nastawienia po uwzględnieniu deklarowanych tendencji motywacyjnych. Wśród uczniów przyznających się do

\footnotetext{
${ }^{5}$ Trzeba jednak podkreślić, że wspomniany artykuł uwzględnił nieco mniejszą grupę badanych, w tym także ponad 80 uczniów nieuczących się niemieckiego. Ankiet uczniów nieuczęszczających na zajęcia j. niemieckiego w niniejszym podsumowaniu z oczywistych względów nie brano pod uwagę. Jednocześnie do analizy dołączono kolejnych 167 odpowiedzi uczących się niemieckiego, pozyskane w semestrze zimowym 2011/2012 i całość wyników zaktualizowano. Częściowo nowe dane nie wpłynęły jednak zasadniczo na zmianę ostatecznych wyników.
} 
słabnącej motywacji (110 badanych) aż 45\% wymieniło negatywne skojarzenia z Niemcami (w tym wulgaryzmy). Pozytywne nastawienie deklaruje 38\% badanych w tej grupie, a $16 \%$ nie ma zdania lub jest ono neutralne.

Z kolei spośród 122 uczniów, którzy uważają, że uczą się coraz chętniej, tylko 8\% wymienia negatywne skojarzenia z Niemcami. Ogromna większość (90\%) ma pozytywne nastawienie do Niemców, 1,5\% (dwie osoby) nie ma zdania na ten temat. $W$ grupie tej brak jest neutralnych odpowiedzi.

Zestawienie zmiennej "tendencja motywacji” ze zmienną „obraz i nastawienie do Niemców" wyraźnie wskazuje na pozytywną korelację: im bardziej rosnąca motywacja, tym lepszy obraz Niemców i pozytywniejsze do nich nastawienie.

\section{Wnioski}

Uwzględnienie dość dużej grupy badawczej obejmującej różne regiony Polski pozwala na sformułowanie konkluzji, które wzbogacają wiedzę na temat aktualnej motywacji i nastawień polskich uczniów wobec nauki języka niemieckiego. Podsumowując powyższą analizę należy jeszcze raz wskazać na kluczowe wnioski:

- Wśród uczniów dominują motywy instrumentalne, przy czym we Wschodniej Polsce są one wyraźniejsze niż w województwach zachodnich.

- "Motyw komunikacyjny" odgrywa na wschodzie mniejszą rolę niż na zachodzie.

- Stosunkowo niewielkie znaczenie mają motywy powiązane z kulturą kraju języka docelowego.

- Pomimo zastosowania bardzo uproszczonego instrumentu badawczego, można przyjąć, iż motywy „integracyjne” (w rozumieniu Gardnera) występują na marginalną skalę.

- Nastawienie do języka niemieckiego jest bardzo pozytywne.

- W kwestii stopnia trudności uczenia się niemieckiego uczniowie są dość równo podzieleni pomiędzy nastawionych pozytywnie i sceptyków, co raczej przeczy stereotypowemu postrzeganiu j. niemieckiego jako bardzo trudnego języka.

- W całej grupie badawczej dominuje pozytywny wizerunek Niemiec i Niemców, zarejestrowano mały odsetek uprzedzeń.

- Odnotowano pewne różnice jakościowe w obrazie Niemiec uczniów ze Wschodniej Polski i uczniów z województw zachodnich.

- Istnieje wyraźna korelacja pomiędzy rosnącą lub słabnącą motywacją do uczenia się j. niemieckiego a wizerunkiem Niemca i nastawieniem 
do Niemców: uczniowie coraz bardziej zmotywowani wykazują skrajnie pozytywne nastawienie do Niemców i społeczeństwa niemieckiego; uczniowie przyznający się do słabnącej motywacji zdradzają bardzo silne uprzedzenia wobec Niemców.

Świadomość faktów wynikających z badań omówionych w niniejszym artykule może mieć dwojakiego rodzaju implikacje. $Z$ jednej strony mogą one stanowić dla badaczy motywacji pewien punkt odniesienia i zachęcać do weryfikacji uzyskanych danych poprzez kolejne, bardziej pogłębione badania empiryczne. $Z$ drugiej strony, tego typu konkluzje winny mieć implikacje programowe i dydaktyczne. Pełniejszy obraz motywacji i nastawień uczniów, czy też ich stereotypów i uprzedzeń daje szansę takiego kształtowania programów i zajęć językowych, które wzmocnią szereg motywów, w tym szczególnie te o charakterze wewnętrznym. Nauczyciel, lepiej poznając motywacje i nastawienia uczniów do języka niemieckiego, może być bardziej skuteczny w swoich działaniach motywujących. Problem jest o tyle istotny, że w polskich realiach edukacyjnych, co potwierdziły także niniejsze badania, język niemiecki jest z reguły drugim, obowiązkowym językiem obcym dla gimnazjalistów i licealistów, rodzi to więc słuszne pytania o siłę motywacji uczniów. Choć badania potwierdziły niewielką motywację wewnętrzną i raczej motywy instrumentalne, to innym istotnym wnioskiem dla nauczycieli jest dominujące pozytywne nastawienie uczniów do języka i społeczeństwa niemieckiego. Świadomość tego potencjału winna być wykorzystana przez nauczycieli do pielęgnowania swoistej asertywności jako dydaktyków języka niemieckiego, nieakceptowania często mitycznych uprzedzeń wobec języka niemieckiego i podjęcia starań o wzmocnienie motywów uczniów, z czasem także tych wewnętrznych.

\section{BIBLIOGRAFIA}

Apelt, W. 1992. «Motive - Motivation - Motivierung». [w:] Jung, U.O.H. (red.). Praktische Handreichungen für Fremdsprachenlehrer. Frankfurt/ Main: Peter Lang. 85-93.

Dörnyei, Z. (2001). Teaching and Researching Motivation. Harlow: Pearson Education.

Gardner, R. C. 2010. Motivation and Second Language Acquisition. The SocioEducational Model. New York: Peter Lang.

Gardner, R. C. 2012. «Integrative motivation and global language (English) acquisition in Poland». [w:] Studies in Second Language Learning and Teaching 2 (2): 215-226.

Gardner, R. C. i Lambert, W. E. 1972. Attitudes and Motivation in Second-Language Learning. Rowley, MA: Newbury House Publishers.

Mackiewicz, M. 2012. "Alte Stereotype neu definiert? Zum Deutschlandbild der polnischen Jugendlichen». [w:] Krasoń, K.J. i Haedrich, B. (red.). Dialog polsko-niemiecki i niemiecko-polski w języku, literaturze i teatrze/Polnisch- 
Motywacja i nastawienia polskich uczniów do nauki języka niemieckiego...

deutscher und deutsch-polnischer Dialog in der Sprache, Literatur und im Theater. Szczecin: PPH Zapol. 171-183.

Netzwerk Deutsch, 2010. Die deutsche Sprache in der Welt. Statistische Erhebungen 2010. Berlin, Bonn, Köln, München: Netzwerk Deutsch.

ORE, 2011. Powszechność nauczania języków obcych w roku szkolnym 2009/2010. Warszawa: Ośrodek Rozwoju Edukacji.

Pawlak, M. 2012. «The dynamic nature of motivation in language learning: A classroom perspective». [w:] Studies in Second Language Learning and Teaching 2 (2): 249-278.

Riemer, C. 2006. "Der Faktor Motivation in der empirischen Fremdsprachenforschung». [w:] Küppers, A. i Quetz, J. (red.). Motivation Revisited. Festschrift für Gert Solmecke. Berlin: Lit Verlag. 35-48. 